\title{
Bergen's role in the medieval North Atlantic trade
}

\author{
KNUT HELLE †
}

Helle, K. 2019. Bergen's role in the medieval North Atlantic trade. AmS-Skrifter 27, 43-51, Stavanger, ISSN 0800-0816, ISBN 978-82-7760-183-0.

North Atlantic trade in the high Middle Ages was centred on Bergen. The Bergen connection was important to the North Atlantic islanders and townsmen who specialized in trading with them, but up to the early fourteenth century did not count for much in Bergen's total trade. This changed when larger assignments of Icelandic stockfish were sent to Bergen from the 1340s and reexported via the town's Hanseatic settlement, the later Kontor. During the fifteenth century fish exports from the North Atlantic to Bergen declined sharply as the English increasingly fetched their fish directly from Iceland, and Hanseatic merchants from Hamburg and Lübeck followed in their wake to Iceland and the more southerly islands. Yet, in the author's opinion, Hanseatic trade with the North Atlantic from Bergen was not reduced to the degree that has often been assumed. And it should not be overlooked that Bergen had economic relations with the North Atlantic islands outside the Hanse.

Knut Helle. University of Bergen, BERGEN, NORWAY (b. 1930 - d. 2015).

Keywords: Bergen, Kontor, Hanseatic trade, stockfish, North Atlantic

In the otherwise rich archaeological material from medieval Bergen there is hardly any significant evidence for the town's medieval trade with the North Atlantic islands. The following discussion, concentrating on Bergen's role in the North Atlantic trade up to the early sixteenth century, is therefore largely based on extant written sources. They show that before 1400 the long-distance trade of the Norse island societies west-over-sea was mostly channeled through Bergen. This was a practice which started to develop in the twelfth century and was more firmly established in the thirteenth century. ${ }^{1}$

Already in the 1180 s and 1190 s contemporary narratives describe Bergen as virtually packed with dried cod, and foreigners from all over northern Europe, above all Englishmen and Germans, came to fetch it in return for their own imports. Among those who brought useful goods to the town were also men from the Norsespeaking island societies of the North Atlantic - Iceland, Greenland, the Faroe Islands, Shetland and Orkney. ${ }^{2}$

The islands were linked to western Norway from the Viking Age by frequently used sailing routes. When the town of Bergen developed into an important node in the high medieval trading network of northern Europe, it became the obvious gateway for islanders who wanted to exchange their goods for Norwegian and foreign commodities. By and large, the lack of native timber brought Icelandic, Greenlandic and Faroese shipping to an end after 1200, and it was left to Norwegian ships and their trading crews to carry people and goods between Bergen and the islands in question. ${ }^{3}$ Norwegian ships sailed between Bergen and Orkney/Shetland as well, but from there the islanders also continued to go to Bergen in their own vessels.

By the mid-1260s all the islands mentioned had come under Norwegian overlordship as skattlond (tax lands), a term which implies regular taxation. The Faroe Islands may have had this status before 1180 and certainly from the early thirteenth century. Shetland became a skattland in 1195, Orkney possibly from 1210, Greenland from 1261 and Iceland from 1262-64." Bergen was the political and administrative centre of the west-oriented Norwegian dominion thus established, ${ }^{5}$ and leading islanders would also go there for political negotiations, which they might combine with trading activities. ${ }^{6}$

Bergen's commercial importance was primarily due to its situation at the head of the coastal sailing route 
from the rich fishing grounds of northern Norway. There, large-scale cod-fishing is first recorded in the first decade of the twelfth century, when it was taxed by the three co-ruling kings of the day, but it must have been going on long before that. The catch was dried on racks in the favourably cold and windy spring climate of the north, and was consequently called stockfish. There are indications of stockfish export from Bergen to eastern England from the second decade of the twelfth century, but it may well have started before the turn of the century, when Bergen was, according to the later saga tradition, founded by King Olaf Haraldsson Kyrre (1067-93). ${ }^{7}$ As there are also ethno-botanical and archeological indications of tendencies towards urbanization in Bergen in the earlier Viking Age, ${ }^{8}$ fish export from there may date even further back. Altogether, it cannot be excluded that there is some connection between the north Norwegian cod-fisheries and the English archaeological evidence for a breakthrough for extensive cod consumption from about AD 1000 and throughout the eleventh and twelfth centuries. ${ }^{9}$

At any rate, north Norwegian stockfish had by the end of the twelfth century become Norway's chief export and the mainstay of Bergen's trading economy. But the town's economic growth was also favoured by its central position in the coastal districts of western Norway and its close links with the North Atlantic islands.

It was preferable for foreign merchants coming to Norway to fetch fish products and other commodities from Bergen and dispose of their imports there rather than sailing their ocean-going ships further north and west. Navigation further up the long coast was best left to smaller native craft. And we have already seen that transportation of goods between the North Atlantic and Bergen after 1200 was taken care of by Norwegian ships, in the case of Orkney and Shetland also by the islanders themselves. Around 1300 Bergen's de facto position as the dominant port of transshipment between Norse areas of production and receiving ports abroad was formally strengthened by regulations which banned the sailing of foreign ships north of the town and westwards to the North Atlantic islands. ${ }^{10}$

Under the new rules exports from these regions should be brought to Bergen and fetched from there by foreign traders. This was a system which for a time operated quite well in practice because it was to the advantage of all parties involved, not least the foreign merchants engaged in the Norwegian trade. They could in short time deliver all their imports in Bergen and load up fully with stockfish and other Norse products. From continental Europe they were able to go to Bergen and return in the same sailing season. Two trips could sometimes be made between Bergen and East English ports in the same season. ${ }^{11}$

The major part of Bergen's foreign trade may have been already in the hands of foreigners in the two last decades of the twelfth century, with English and German merchants in the lead. Hanseatic Germans were the chief agents of the town's rapid economic growth in the latter part of the thirteenth century. By the first decade of the fourteenth century they controlled a market area which covered the southern and eastern coast of the Baltic, north-western continental Europe and the Rhine regions. They had also come to handle the bulk of Bergen's particularly important commercial exchange with the east English ports of the Wash and the Humber estuary. In the following decade Norwegian sailings to England declined, and after 1320 it was largely left to the English to defend a secondary position in Bergen's trade with eastern England. ${ }^{12}$

Information on the North Atlantic trade with Bergen in the high Middle Ages is mainly qualitative, defying reliable quantification. A telling glimpse of Icelandic exports to Bergen can be caught from a document of 1312 witnessing the sale of an urban estate in the town. The buyer was a townsman who traded with Iceland and paid for a large part in Icelandic goods - various types of wadmal, cattle hides, goatskins, sheepskins and butter, of which wadmal (ON vaðmál) was clearly most important. ${ }^{13}$ In Norway it was used for sails, clothing (not least working clothes for land and sea), bedding, tents, packaging and other purposes. ${ }^{14}$ Sagas, annals and legal provisions confirm that products of animal husbandry, including wadmal, were the main Icelandic exports up to the early fourteenth century, supplemented by gyrfalcons and sulphur. Among the imports to Iceland grain products (mainly flour and meal), lumber, tar, wax, canvas and finer linen cloth appear to have been important. Wine and beer, honey, woollen cloth, lead, tin and objects of finer metals were also brought in. ${ }^{15}$

In the late Middle Ages wadmal was also sent or collected to Bergen from the Faroe Islands and Shetland, and may have been brought there already in the high Middle Ages, together with wool, butter, tallow, hides and skins, down and feathers of seabirds. The goods brought back from Bergen were probably largely the same as those sent to Iceland. Timber must have been particularly important, not only in the Faroe Islands and Shetland, but also in Orkney. The Orcadians were on their part able to supply Bergen with cereals, mainly barley, in addition to the products of animal husbandry. ${ }^{16}$ Norwegian trade with the Norse Greenlanders, few and far away as they were, was never extensive, and had more or less ceased by $1400 .^{17}$ 
Goods from the North Atlantic found a market partly in Norway, partly abroad. In the latter case they were exported from Bergen by Hanseatic and other foreign merchants, and up to the early fourteenth century also by Norwegians. The demand for wadmal was great in Norway, and most of the imported fabric seems to have been put to use there. ${ }^{18}$ Cereals from Orkney would obviously also be consumed in Norway. But in hides, skins and other yields of animal husbandry Norway was more than self-sufficient. One would therefore expect such imports to Bergen from the North Atlantic to be at least partly re-exported.

For the years 1303-11 commodities in the trade with Bergen are recorded in the customs accounts of the ports of the Wash and the Humber estuary - Lynn, Boston, Ravensere and Hull. They show that German merchants were by then handling most of the imports to England from Bergen, with Norwegians still active on their side. ${ }^{19}$

Stockfish and other fish products now completely dominated the imports of both Germans and Norwegians. Stockfish may have amounted to approximately $82 \%$ of the total value of the commodities brought in from Norway, fish oil coming next with $8 \%$, supplemented by herring with $3 \%$. Timber may have counted for $4 \%$, hides and skins for $3 \%$ and other commodities for $1 \%$. English merchants, too, imported stockfish and other goods from Bergen, but as they did not pay customs in their home ports, their loads are not quantifiable. Altogether, it appears that England may have imported 1500-2000 tons of Norwegian stockfish annually in the period 1303-11, almost all of it via Bergen. Contemporary exports to the north-western of Europe, Lübeck and other Baltic towns, are not quantifiable. But according to an educated guess they equalled the amount going to England, so that 3000-4000 tons may have been exported in total. ${ }^{20}$

Due to the catastrophic Norwegian and western European loss of population caused by the Black Death and following outbreaks of plague, the total Norwegian stockfish exports may in the last decades of the fourteenth century have declined to half the amount exported at the beginning of the century, or even less. ${ }^{21}$ From about 1520 production and exports started to rise again, reaching more than 4500 tons at the end of the sixteenth century. ${ }^{22}$

At the beginning of the fourteenth century fish products had barely started to be sent to Bergen from the North Atlantic. Consequently, re-exportation of island produce to England can only have constituted a minimal part of the total Bergen exports. Such products must be sought among the approximately $3 \%$ of hides and skins and $1 \%$ of other goods that went to England. As the origins of imported hides and skins are not specified in the customs accounts, one can only assume that part of them came from the North Atlantic. For the rest sulphur from volcanic Iceland was of certain North Atlantic origin. ${ }^{23}$ It also seems probable that the gyrfalcons mentioned a few times in the customs accounts came mostly from Iceland or Greenland, ${ }^{24}$ and that at least part of the wadmal recorded there was of Icelandic origin. ${ }^{25}$

It should be added that sulphur and grey and white falcons were already among the commodities reported to have been brought to France on a ship from Norway around $1226 .{ }^{26}$ When customs in 1316 were imposed on foreigners' exports from Norway, sulphur and wadmal were among the goods liable to such duties. ${ }^{27}$

Altogether, it can be safely concluded that part of the goods sent to Bergen from the North Atlantic were up to the early fourteenth century re-exported to England and other foreign destinations. The east English customs accounts confirm that Hanseatic merchants had come to dominate this exchange, with Norwegians still at their side. But North Atlantic produce can only have constituted a minimal part of Bergen's total exports to east English ports. The same would probably apply to the town's trade with the Baltic and the north-western European continent. The chief Icelandic export of wadmal to Bergen must have been meant mainly for the Norwegian market, as were also Orkney cereals and part of other island produce sent to Bergen. The economic interplay with Bergen was important to the islanders and the townsmen who specialized in trading with them, but with the possible exception of wadmal, it hardly amounted to much in Bergen's total high medieval trade. This would change when larger consignments of stockfish started to be sent to Bergen from Iceland.

\section{The North Atlantic fish trade}

It seems that Icelandic fishing for domestic consumption grew in importance from the twelfth century and that cod had become common food by the mid-thirteenth century, helped by the religious rules about fasting. But stockfish was hardly exported from Iceland for commercial reasons until around 1300. There is evidence of such exports in 1307, when a German merchant brought a small consignment of Icelandic fish (piscibus de Islonde) to Boston from Bergen on a ship whose skipper was probably a Lübecker. ${ }^{28}$ A nascent stockfish export is also indicated by restrictions from 1294 and 1319 on taking away cod from Iceland in years of famine. ${ }^{29}$

Yet there is no evidence of more extensive Icelandic fish export to Bergen until the years 1340-47 when there was a marked increase in Norwegian sailings to Iceland. 
Up to eleven, twelve and even thirteen ships would call in a year, as compared with only one ship in 1324 and 1333 and none at all in 1326. There is little doubt that the Norwegians came mainly for stockfish. ${ }^{30}$ At least five of the ocean-going ships calling at Iceland in the 1340s hailed from the Bergen area, and some of them had been sailing to the east English ports in the first decade of the century. Together with most other Norwegian ships visiting Iceland, they must have carried their loads back to Bergen. ${ }^{31}$

Sailings to Iceland stopped when the Black Death struck Norway in 1349-50, and took time to recover. But after 1375 quite a few Norwegian ships are again reported to have visited Iceland. In 1388 eleven of them were coming out, in addition to three which had wintered from the previous year. In 1382 or 1383 an earlier import duty was imposed on Icelandfarers bringing stockfish, fish oil, wadmal and sulphur to Bergen; they were to pay six fishes from each imported hundreds of stockfish. In 1392 the purchase of part of an urban estate in Bergen was paid with Icelandic fish, and in 1409 two Bergen town councillors were active as merchants in Iceland. Altogether, Icelandic fish export to Bergen may have reached a second peak in the two last decades of the fourteenth century. ${ }^{32}$

Dried Icelandic cod was not stockfish in the original sense of the word. Iceland lacked wood for constructing racks of Norwegian type where fish could be hung on rods to dry. The cod was put to dry on rocks, stones or gravel, and was later reputed to be of lower quality. The Icelandic practice spread to the Finnmark region in northernmost Norway, where wood was scarce, and hurt the reputation of Bergen stockfish. In 1494 the Hanseatic trading settlement or 'Kontor' in Bergen demanded that this had to stop. The claim was supported by Bergen authorities, North-farers bringing fish to the town and local officials in Finnmark. ${ }^{33}$

Nevertheless, Icelandic stockfish was clearly in demand in Bergen for re-export in the latter part of the fourteenth century, but in the 1390 s there are also signs that the English had started to fetch fish directly from southwestern Iceland. ${ }^{34}$ After 1412 they are reported to have come there on numerous ships, both as fishermen and merchants. In 1413 there were thirty English fishing vessels in Icelandic waters, and twenty-five are reported to have sunk there in 1425. In 1414 five English merchant ships visited Vestmannaeyjar (Westman Islands), and in 1415 six of them put in at Hafnarfjörður, south of present Reykjavík, hereafter the main English port of call. ${ }^{35}$ The English merchants bought stockfish produced by the Icelanders. Their trade declined from the 1470s and even more after about 1540, due partly to German competition and partly to the restrictions put on it by the DanoNorwegian crown.

English fishermen had started to catch and salt cod and herring in the North Sea from about 1370, before they went on to fish for cod and salt it in Icelandic waters. Altogether, the result was that Icelandic stockfish and salted fish from Icelandic waters replaced Bergen stockfish on the English market. ${ }^{36}$

In the first phase of their voyages to Iceland the English were still active in the Bergen fish trade. Some of them had settled in the town in the two last decades of the fourteenth century and eventually organized themselves along the same lines as the Hanseatic Kontor, but on a lesser scale. When the German winter residents left Bergen in 1427-33 because of the Hanse's warfare with the Dano-Norwegian king, ${ }^{37}$ the English were sufficiently well established to take advantage of the situation. In the 1420 s and 1430 s they also made passing attempts at fetching fish directly from northern Norway. In Bergen the Kontor had earlier put obstacles in their way, and continued to do so after 1433 . That must have strengthened their motivation for sailing directly on Iceland. At any rate, the Icelandic connection proved so advantageous that English trade with Bergen declined sharply in the mid-fifteenth century, but it never ceased entirely. ${ }^{38}$

In the second decade of the fifteenth century Hanseatic merchants started to make themselves felt in the North Atlantic beside the English. ${ }^{39}$ In 1416 a Hanse Diet responded to a complaint from the Bergen Kontor by passing penal provisions against people from Hanse ports who had a few years earlier started sailing to Orkney, Shetland and the Faroe Islands. In 1425 the Dano-Norwegian king banned German sailings to Iceland as well. The Hanseatic engagement in the Icelandic stockfish trade was headed by Hamburg merchants. It seems to have started around 1420 and was expanded after 1480 .

It was in vain that the Dano-Norwegian authorities and the Bergen Kontor, backed by the Hanse, reacted against the early English and Hanseatic voyages to Iceland, in defence of Bergen's rights as the legal port of transshipment between the North Atlantic and foreign areas. Later the Hamburgers sought co-operation with the Dano-Norwegian crown. In 1468 they obtained licences to sail to Iceland from King Christian I. It was of no avail that the licences were repealed by the Norwegian council of the realm after the king's death in 1481 and that the Kontor continued to defend Bergen's traditionally central role in the North Atlantic trade. Lübeck and the other 
Wendish ports of Wismar, Rostock and Stralsund - the dominant towns behind the Kontor - eventually reconciled themselves with the situation, and opted for free Hanseatic sailings on Iceland in 1494. In 1484 merchants from Bremen are mentioned alongside the Hamburgers, and by the 1490s a few Lübeckers had started to take part in the Icelandic trade. In the first part of the sixteenth century the Hanseatic merchants ensured supremacy over the English in the Iceland trade, partly by violent means. That is why that century is commonly named the 'German Century' of Icelandic history. ${ }^{40}$

At first, some of the Hamburgers sold their Icelandic fish in England. But gradually, and particularly after 1500, direct and more frequent sailings to Hamburg and other Hanse ports prevailed. In 1513 German merchants, townspeople and counsellors of the realm in Bergen complained that people from Hamburg, Bremen and other Hanse towns now brought Icelandic fish directly to North Sea ports. They induced King Christian II to decree that such fish should only be sent to England, as was the earlier practice. In 1514 the Bergen Kontor reported that while Hamburg had earlier on sent one or two ships with Icelandic fish to England, nowadays six, eight and often ten ships went to Iceland to bring home fish.

From the early fifteenth century the direct English and Hanseatic connection with Iceland must have led to a sharp decline in the import of Icelandic stockfish to Bergen, ${ }^{41}$ but we shall see that it did not cease completely and that it may have been kept up to a larger extent than commonly assumed.

In the interest of the Bergen Kontor the Hanse maintained its formal ban on direct sailings to the Faroe Islands, Shetland and Orkney throughout the late Middle Ages, but to no avail. Bremen merchants were the most active in this trade, going primarily to Shetland, while the Hamburgers came to dominate in the Faroe Islands. In the sailing season the Bremen merchants set up their booths in the ports of Shetland, and exchanged their imports for stockfish and other native products. In 1498 they were accused of having fraudulently mixed Shetland stockfish with Bergen fish of better quality. This was also done later on, partly by mixing the two kinds of fish in the North Sea ports, partly by bringing Shetland stockfish to Bergen and mixing it with Norwegian stockfish there.

In a Hanse Diet in 1525 envoys from Bremen advocated that Shetland fish should go directly to the Hanse towns and not to Bergen, reportedly to avoid mixing with Bergen fish. The proposal reveals the strong position now attained by Bremen in the Shetland trade. It also shows that some Shetland fish was brought to Bergen towards the end of the Middle Ages. ${ }^{42}$

\section{Bergen in late medieval North Atlantic trade}

Bergen's role in the North Atlantic trade of the late Middle Ages, from the mid-fourteenth up to the early sixteenth century, was partly shaped by the policies of the German Hanse and the Hanseatic trading station which was more firmly established in the town around 1360 - one of the four most important Hanseatic settlements outside the German Realm for which the term Kontor was later reserved. The other three were those of London, Bruges and Novgorod. ${ }^{43}$

The seed for the Kontor had been sown by the Hanseatic 'winter-sitters' who took up all-year-round residence in Bergen from the end of the 1250 s and gradually came to control the town's middle-man trading. They were probably in most cases managers or junior partners of capitalists in their home towns, above all in Lübeck, as was later the case at the established Kontor. The winter residents were active in shipping out stockfish and other Bergen exports, and also supplied the non-resident Hanseatic summer 'guests' who visited Bergen in increasing numbers. In return they received imports which enabled them to buy fish and other goods available in Bergen at all times of the year and to start shipments abroad from the beginning of the sailing season.

Grain was the chief import to Bergen in return for fish products, which meant that merchants from Lübeck, from the other Wendish towns of Wismar, Rostock and Stralsund, and from German towns of the Baltic in general had an advantage over their competitors from North Sea ports such as Hamburg, Bremen, Kampen and Deventer. Lübeckers were the leading winter residents in Bergen. And the council of Lübeck headed the negotiations with the Norwegian crown which in the second half of the thirteenth century secured for German summer guests' legal protection, reliefs and privileges ahead of other foreigners in Bergen. ${ }^{44}$

The Lübeckers also came to dominate the established Bergen Kontor. They were supported by their home town in an alliance with Wismar, Rostock and Stralsund which was not without tensions. It was Lübeck's policy to obstruct the access of merchants from the North Sea ports to Baltic grain which they could use in exchange for fish and other products in Bergen. Even though Hamburg, Bremen and the Zuidersee ports of Kampen and Deventer were members of the more comprehensive Hanse body established in the 1350s, their merchants were both in this and other ways discriminated against at the Kontor. This must have strengthened the motivation of Hamburg and Bremen merchants to start the 
above-mentioned voyages to the North Atlantic islands in the early fifteenth century.5

The Kontor fastened its grip on middle-man trading in Bergen with the help of a systematic and extensive credit system. There are indications that it had started to develop among the Hanseatic winter residents already before the establishment of the Kontor, but it is not fully known until the following period. A group of clients or kopnoten was established around each firm of the Kontor and they were tied to the firm as receivers of advance payments in goods and equipment. Most important were the Northfarers (nordervaren) who brought stockfish and other fish products to the Kontor from northern Norway. But in the debt registers were also to be found the names of people from the North Atlantic islands. ${ }^{46}$

In his will from 1429 a Lübeck Bergenfahrer, one of the merchants who traded to Bergen and had an owner's share in one of the Kontor firms, reduced the debts owed him by Icelanders, Shetlanders and Faroese according to his 'letters, rolls and books'. In 1475 another Bergenfarer bought a share in a Kontor firm to which people from the same islands were indebted. ${ }^{47}$ In 1476 the bishop of Bergen and the master of the royal chapels supported the efforts of a Hanseatic merchant to regain goods taken from him in the two preceding years by English merchants in Iceland, mainly stockfish, fish oil and other fish products. It appears that he had followed a Norwegian ship from Bergen to Iceland in order to trade there. ${ }^{48}$

This goes to show that some Icelandic and other North Atlandic trade was still carried out by Hanseatic merchants from Bergen in the second half of the fifteenth century. In other words, the decline in the import of Icelandic stockfish to Bergen from the early fifteenth century was not absolute. When the Hanse gave up its ban on direct sailings to Iceland at the end of the century and a few Lübeckers started to take part, it may have eased the conditions for sending some Icelandic fish abroad via the Bergen Kontor.

From Shetland we have seen that Bremen merchants brought fish to Bergen at the end of the century and mixed it with Norwegian stockfish. The fact that the Hanse upheld its formal ban on direct sailings to Shetland, the Faroe Islands and Orkney may reflect that the Kontor's economic connections with these islands were better maintained than those with Iceland. Not least stockfish and other fish products may still have gone to Bergen from Shetland and the Faroe Islands.

Merchants from Hamburg and Bremen continued to take an active part in the Bergen trade throughout the late Middle Ages, notwithstanding their direct connections with the North Atlantic islands. In the early sixteenth century they took advantage of the Kontor's loosening grip on Bergen's export trade. Merchants from the Wendish towns now ceased sailing to the north-western Continent, bringing fish there from Bergen. Consequently, many of the Kontor firms preferred selling their fish to summer guests from the north-western Continent, rather than sending it to Lübeck for further distribution..$^{9}$ Hamburg and Bremen merchants now increased their sailings to Bergen. In the years 1518-21 they each sent nineteen ships to Bergen, on the average five per year, and the Hamburgers were particularly active in the town..$^{50}$ There were hardly watertight bulkheads between the trades of the two North Sea ports with the North Atlantic and Bergen, and they may have shipped North Atlantic produce via Bergen to a higher degree than indicated by the Bremen merchants' mixing of Shetland and Bergen stockfish from the end of the fifteenth century.

There is little doubt that Bergen's role in Hanseatic trading with the North Atlantic islands was strongly reduced during the fifteenth century, but probably not to the degree which has been sometimes assumed. Bergen's position in the North Atlantic trade may even have regained some of its former strength when Hamburg and Bremen merchants increased their sailings to Bergen. The days were now over when the Wendish towns and the Kontor could dictate the Dano-Norwegian government's policy, and this allowed merchants from Hamburg and Bremen a freer hand in the Bergen trade..$^{51}$

Bergen's role in the late medieval economy of the North Atlantic islands was not restricted to the Hanseatic trade carried out from the town. Bergen was still, although to a diminishing degree, the administrative centre of the North Atlantic islands. The royal income from the tax lands was paid into the Bergen treasury, for which the captain of the royal estate in Bergen (named Bergenhus castle from the 1520s) was responsible. But there was hardly any income from Greenland after 1400, and the payments from Orkney and Shetland ceased when the islands were pawned to the Scottish king in 1468-69. At that time the royal revenue from Iceland was still paid into the Bergen treasury, but later on it went directly to the Dano-Norwegian king. Of the former tax lands, only the Faroe Islands yielded royal income to Bergen towards the end of the Middle Ages. But Hamburg merchants had great influence there in the 1520s, and in 1529 the Faroe Islands were given in fief to one of them, Thomas Koppen. Two years later he shared his rights with Joachim Wullenweber, another Hamburger. ${ }^{52}$

As long as royal income from the North Atlantic islands reached the Bergen treasury it was, like the revenue from 
Norway proper, mostly paid in kind. As treasurerer, the captain of the royal estate would trade part of it in exchange for other desirable commodities, and for that purpose he would both enter into business connections with Kontor firms ${ }^{53}$ and sell goods outside the Kontor. ${ }^{54}$ In both cases island produce may have become part of Bergen exports.

It should also be noted that two of Bergen's religious institutions had income in kind from North Atlantic islands. St Michael's monastery (Munkeliv) owned land in Orkney and Shetland, and received rent from there. Bergen's main royal chapel, the Church of the Apostles, had income in the form of butter, tallow and wadmal from the Faroe Islands and Shetland. Norwegians could also privately possess land in the islands and receive land rent from there. Thus, the royal lawman of Bergen is reported to have bought land in Shetland in $1509 .{ }^{55}$ Like the royal revenue, such ecclesiastical and private income from the North Atlantic may in part have been traded in Bergen, and some of it may have been exported.

The Orcadians and Shetlanders were not prevented from sailing to Bergen by the fact that Hanseatic merchants from Hamburg and Bremen traded directly with the islands from the early fifteenth century, even though it was at the cost of the Bergen Kontor. Nor was the final Scottish annexation of the Orkney and Shetland in 1471 harmful to this traffic. On the contrary, it strengthened the conditions for Scoto-Norwegian trade. In the following decades Scottish ships frequently visited Bergen and other parts of western and southern Norway. A number of Scots even settled in Bergen and became members of the growing number of burgesses who made themselves felt as competitors of the Kontor in the town's internal and foreign trade. The group of 'Scots' included Orcadians (see below), which often makes it impossible to separate them from people from the Scottish mainland.

The new burgesses formed only the crest of a veritable wave of immigrants from Scotland, Orkney, Shetland and the Faroe Islands from the early sixteenth to the late seventeenth century. The population of the islands was apparently growing faster than the means of livelihood in this period, but probably more so in Shetland and the Faroe Islands than in Orkney. The immigrants sought their fortune in Bergen, but young people from Shetland and the Faroe Islands also found work in the fishery districts along the coast of western and northern Norway. The Orcadians seem to have been generally more established, and might end higher up in the social strata of Bergen and the coastal districts. ${ }^{56}$

The immigration from the west must have strengthened the economic ties between Bergen and the island societies of Orkney, Shetland and the Faroe Islands. This is strikingly confirmed by a dramatic episode in 1523. In that year members of the Kontor and the German crafts' guilds of Bergen staged a brutal midnight assault on competing burgesses. The chief victims were a group of 'Scots' who were deprived of money and commodities which were later claimed to be worth more than 38,000 marks.

One of the Scots was the Orcadian John Thommesen, who claimed that he had been robbed of gold, silver, money and commodities worth close on 11,000 marks. He was a town councilor and the owner of a retail shop, and later became burger master of Bergen. His stock included velvet, damask, English and Dutch cloth, Shetland and Faroese wadmal and down, Scottish wool, hides and furs, English tin and various spices and foodstuffs. He also traded in timber and was the owner of several sloops and boats and at least one ship. His range of commodities reveals that he was in commercial contact with Scotland, Orkney, Shetland and the Faroe Islands. From Orkney and Shetland he may have imported wadmal, down, malt and hides, exporting lumber and boats in return.

The second largest loss was suffered by Sander Johnson, amounting to about 9500 marks. He, too, was robbed of wadmal, not only from Shetland and the Faroe Islands but also from Iceland, and of Scottish wool and English tin. Like John Thommesen he was the owner of boats and sloops, and additionally half a ship.

John and Sander also traded in stockfish. John bought a large consignment from the captain of Bergenhus in $1520,{ }^{57}$ and both of them may have bought stockfish from Shetland and the Faroe Islands, if they did not get it from northern Norway or from Northfarers bringing it to Bergen. They probably used their ships and possibly also their sloops for transporting goods between Bergen and the islands to the west. And they may have sold stockfish and other goods to foreign summer guests visiting Bergen.

This goes to show that Bergen's role in late medieval North Atlantic trade was not limited to the strongly reduced participation of the town's Hanseatic Kontor. Norwegian ships were still crossing the ocean to Iceland and the Norse island societies further south. Orcadians and Shetlanders continued and apparently even stepped up their sailings on Bergen towards the end of the Middle Ages. Goods were brought from Orkney, Shetland and the Faroe Islands, and traded outside the Kontor. Bergen burgesses took part in the stockfish trade and sold their stocks to foreign summer guests without involving the Kontor firms. The Hanseatic attack on the town's Scottish burgesses in 1523 should be seen as a particularly drastic reflection of the changes which were now taking place in the Bergen trade. 


\section{Endnotes}

${ }^{1}$ Helle 1982a, 114-116, 160-170, 346-352; Helle 2005a, 23-25.

${ }^{2}$ Sverris saga, 110-111; Scriptores minores historiae Danicae medii aevi 2, 474-476.

${ }^{3}$ Jóhannesson 1969, 78-79, 274-277; Helle 1982a, 360-364, 395, 399.

${ }^{4}$ Helle 2005b.

${ }^{5}$ Helle 2013.

${ }^{6}$ Helle 1982a, 348-350, 363-364; Helle 2013, 116.

${ }^{7}$ Helle 1982a, 114-116.

${ }^{8}$ Helle et al. 2006, 45-48.

${ }^{9}$ Cf. Barrett et al. 2004.

${ }^{10}$ DN V, 23-24; NGL III, 134, 170. On Bergen's development into the staple of West-Scandinavian foreign trade, see Helle 1982a, 346-354; cf. Nedkvitne 2014, 310, 476. An English survey in Helle 1982b.

${ }^{11}$ Helle 1982a, 402.

${ }^{12}$ Nedkvitne 2014, 38, 52-53, 65-66, 79, 80-85.

${ }^{13}$ DN I, no. 134; cf. Helle 1982a, 274.

${ }^{14}$ Porláksson 1991 is the main work on the important role of wadmal in the high medieval Icelandic economy. On the exportation of wadmal to Norway and Bergen, see particularly pp. 364-432.

${ }^{15}$ Jóhannesson 1969, 256-267; Helle 1982a, 309-311, 317.

${ }^{16}$ Helle 1982a, 309-310, 337; Thompson 1987, 110-111, 208-209; Porláksson 1991, 430-432.

${ }^{17}$ For particulars on the Greenland trade, see Blom 1960; Helle 1982a, 362-363, 811.

${ }^{18}$ Porláksson 1991, 432-433.

${ }^{19}$ Nedkvitne 2014, 55-79.

${ }^{20}$ Ibid., 69-72, 93.

${ }^{21}$ Ibid., 245-247.

${ }^{22}$ Ibid., 265.

${ }^{23}$ Sulphur recorded by Nedkvitne 2014, 58, 597-599, 607, 610, 612.

${ }^{24}$ Ibid., 59, 600, 607, 610, 613.

${ }^{25}$ Ibid., 58, 600, 603-604, 613.

${ }^{26}$ Ibid., 35.

${ }^{27}$ NGL III, no. 47; cf. Helle 1982a, 305-306.

${ }^{28}$ DN XIX, p. 515; Nedkvitne 2014, 606 with n. 10.

${ }^{29}$ Porláksson 1991, 450-451.

${ }^{30}$ Jóhannesson 1958, 147; Porláksson 1991, 452-454.

${ }^{31}$ Helle 1982a, 361-362.

${ }^{32}$ Ibid., 811; Porláksson 1991, 454-455.

${ }^{33}$ Nedkvitne 2014, 477-78; cf. Helle 1982a, 776-477.

${ }^{34}$ Porláksson 1977, 178-179.

${ }^{35}$ Ibid.

${ }^{36}$ Nedkvitne 2014, 185-186.

${ }^{37}$ See paper by Geir Atle Ersland in this volume.

${ }^{38}$ Helle 1982a, 788-792; Nedkvitne 2014, 146, 173-183.

${ }^{39}$ The following account of the Hanseatic sailings to the North Atlantic islands is documented by Helle 1982a, 798-799; see also Friedland 1973 for a more detailed treatment of the German trade with Shetland.

${ }^{40}$ For an in depth examination of the policies of the Hanse concerning the North Atlantic islands, see Hammel-Kiesow in this volume.

${ }^{41}$ Porláksson 1977, 178-179; Helle 1982a, 811.
${ }^{42}$ Helle 1982a; Friedland 1973.

${ }^{43}$ Helle 1982a, 730-34; Nedkvitne 2014, 334-336.

${ }^{44}$ Helle 1982a, 378-390, 472-485. See the wide-ranging discussion of how and why the Germans achieved their dominant economic position in Bergen in Nedkvitne 2014, 277-332.

${ }^{45}$ Helle 1982a, 748-749, 792-794, 797-798.

${ }^{46}$ Ibid., 359-360, 730, 734-740, 770-771; Nedkvitne 2014, 400-418.

${ }^{47}$ Bruns 1900, 61, 177; cf. Helle 1982a, 806; Nedkvitne 2014, 403.

${ }^{48}$ DN III, no. 914; $c f$. Helle 1982a, 806.

${ }^{49}$ Nedkvitne 2014, 242-243.

${ }^{50}$ Helle 1982a, 775, 799-800.

${ }^{51}$ Ibid., 800.

${ }^{52}$ Ibid., 331, 830, 832, 835, 863-864.

${ }^{53}$ Ibid., 771-772, 816, 837.

${ }^{54}$ For example NRJ III, 562.

${ }^{55}$ Helle 1982a, 336-337, 852.

${ }^{56}$ Ibid., 804-805.

${ }^{57}$ HR III 9, no. 482; NRJ III, 562; Helle 1982a, 815- 816; Nedkvitne 2014, 484-485.

\section{References}

Printed sources (see also list of abbreviations)

NRJ - Norske Regnskaber og Jordebøger fra det 16de Aarhundrede. Christiania: Det norske historiske Kildeskriftfond, 1887-.

Scriptores minores historiae Danicae medii aevi, vol. 2, ed. by M. Cl. Gertz. København: Selskabet til udgivelse af kilder til dansk historie, 1920.

Sverris saga - Sverris saga etter Cod. AM $3274^{\circ}$, ed. by G. Indrebø. Kristiania: Den Norske Historiske Kildeskriftkommission, 1920.

\section{Secondary literature}

Barrett, J. H., Locker, A. M. and Callum, C. M. 2004. The origins of intensive marine fishing in medieval Europe: the English evidence. Proceedings of the Royal Society of London B 271, 2417-2421.

Blom, G. A. 1960. Grønlandshandel. Kulturhistorisk leksikon for nordisk middelalder, vol. 5, 519-523. Oslo: Gyldendal Norsk Forlag.

Bruns, F. 1900. Die Lübecker Bergenfahrer und ihre Chronistik, Hansische Geschichtsquellen, vol. 2. Berlin: Pass \& Garleb.

Friedland, K. 1973. Der hansische Shetlandshandel, in K. Friedland (ed.), Stadt und Land in der Geschichte des Ostseeraums, 66-79. Lübeck: Schmidt-Römhild.

Helle, K. 1982a. Bergen bys historie, vol. 1. Kongssete og kjøpstad. Fra opphavet til 1536. Bergen: Universitetsforlaget.

Helle, K. 1982b. The Germans in Bergen in the Middle Ages, in Bryggen, The Hanseatic Settlement in Bergen, 12-26. Det Hanseatiske Museums Skrifter, no. 24, Bergen.

Helle, K. 2005a. The emergence of the town of Bergen in the light of the latest research results, in A. Grassmann (ed.), Das Hansische Kontor zu Bergen und die Lübecker 
Bergenfahrer, 12-27. Lübeck: Archiv der Hansestadt Lübeck.

Helle, K. 2005b. The position of the Faeroes and other 'tributary lands' in the medieval Norwegian dominion, in A. Mortensen and S. V. Arge (eds), Viking and Norse in the North Atlantic, 11-21. Annales Societatis Scientiarum Færoensis Supplementum XLIV. Tórshavn: Føroya Fróðskaparfelag.

Helle, K. 2013. The political centre of the high medieval Norwegian realm, in Ø. H. Brekke and G. A. Ersland (eds), Håkonshallen 750 Years, Royal Residence and National Monument, 110-121. Oslo: Dreiers Forlag.

Helle, K., Eliassen, F.-E., Myhre, J. E. and Stugu, O. S. 2006. Norsk byhistorie. Urbanisering gjennom 1300 år. Oslo: Pax forlag.

Jóhannesson, J. 1958. Îslendinga saga, vol. 2. Reykjavík: Almenna bókafélagið.
Jóhannesson, J. 1969. Islands historie i mellomalderen, Fristatstida. Oslo: Universitetsforlaget.

Nedkvitne, A. 2014. The German Hansa and Bergen 1100-1600. Quellen und Darstellungen zur hansischen Geschichte, vol. 60. Köln: Böhlau.

Thompson, W. P. L. 1987. History of Orkney. Edinburgh: The Mercat Press.

Porláksson, H. 1977. Island. Urbaniseringstendenser på Island i middelalderen, in G. A. Blom (ed.), Urbaniseringsprosessen i Norden, vol. 1, 161-188. Oslo: Universitetsforlaget.

Porláksson, H. 1991. Vaðmál og verðlag. Vaðmál í utanlandsviðskiptum og búskap Íslendinga á 13. og 14. öld. Reykjavík: Heimspekideild Háskóla Íslands. 